\title{
The SPFH Protein Superfamily in Fungi: Impact on Mitochondrial Function and Implications in Virulence
}

\author{
Marienela Y. Heredia (D) and Jason M. Rauceo *(D) \\ Department of Sciences, John Jay College of the City University of New York, New York, NY 10019, USA; \\ heredia3@wisc.edu \\ * Correspondence: jrauceo@jjay.cuny.edu
}

Citation: Heredia, M.Y.; Rauceo, J.M The SPFH Protein Superfamily in Fungi: Impact on Mitochondrial Function and Implications in Virulence. Microorganisms 2021, 9, 2287. https://doi.org/10.3390/ microorganisms 9112287

Academic Editor: J.H. (Han) de Winde

Received: 30 September 2021 Accepted: 1 November 2021 Published: 3 November 2021

Publisher's Note: MDPI stays neutral with regard to jurisdictional claims in published maps and institutional affiliations.

Copyright: (c) 2021 by the authors. Licensee MDPI, Basel, Switzerland. This article is an open access article distributed under the terms and conditions of the Creative Commons Attribution (CC BY) license (https:/ / creativecommons.org/licenses/by/ $4.0 /)$.

\begin{abstract}
Integral membrane proteins from the ancient SPFH (stomatin, prohibitin, flotillin, HflK/ $\mathrm{HflC}$ ) protein superfamily are found in nearly all living organisms. Mammalian SPFH proteins are primarily associated with mitochondrial functions but also coordinate key processes such as ion transport, signaling, and mechanosensation. In addition, SPFH proteins are required for virulence in parasites. While mitochondrial functions of SPFH proteins are conserved in fungi, recent evidence has uncovered additional roles for SPFH proteins in filamentation and stress signaling. Inhibitors that target SPFH proteins have been successfully used in cancer and inflammation treatment. Thus, SPFH proteins may serve as a potential target for novel antifungal drug development. This review article surveys SPFH function in various fungal species with a special focus on the most common human fungal pathogen, Candida albicans.
\end{abstract}

Keywords: SPFH; prohibitin; stomatin; mitochondria; fungi

\section{Introduction}

The SPFH protein family is present in all domains of life. Proteins of this family are characterized by a conserved SPFH domain and diverge highly at their N- and C-terminal regions [1-4]. Furthermore, the distribution of SPFH proteins across species varies [1,2,4]. Proteomic and cellular analyses identified SPFH proteins in various cellular membranes, such as the inner mitochondrial membrane and plasma membrane [5-12]. SPFH proteins also localize to the endoplasmic reticulum and lysosome/vacuole $[5,13,14]$. Biochemical events dependent on SPFH proteins include palmitoylation and oligomerization and have supported a hypothesis that SPFH proteins are membrane scaffolds [15]. In vitro biochemical results showed that human stomatin protein binds directly to cholesterol and actin mainly through key amino acid sequences in the C-terminus [16]. Moreover, sequences in the SPFH domain are required for SPFH protein homo-oligomerization [16,17]. However, the details underlying the molecular function of SPFH proteins are limited.

SPFH proteins in mammals carry diverse functions. Prohibitin 1 (PHB1) and prohibitin 2 (PHB2) regulate mitophagy, or the removal of damaged mitochondria [18,19]. Stomatinlike protein 2 (SLP2) is required for respiratory chain complex assembly and mitochondrial translation [15,20-22]. Additional physiological roles associated with mammalian and nematode SPFH proteins include signaling, mechanosensation, and ion transport [23-26]. Importantly, disruption of SPFH protein function has been linked to several life-threatening conditions in humans, such as cancer, Alzheimer's disease, kidney disease, and cardiac disease [27-29].

Several parasites require SPFH proteins for virulence. In the malaria-causing parasite, Plasmodium berghei, the prohibitin-like protein PHBL maintains mitochondrial membrane potential, and phbl-mutants failed to colonize their mosquito host [30]. Protozoan parasites from the genus Leishmania colonize vertebrate macrophages, causing chronic and debilitating skin diseases [31]. In L. major, mitochondrial prohibitin 1 and prohibitin 2 mediate survival in response to macrophage-induced oxidative stress [31]. Lastly, in the parasite, 
Trypanosoma brucei, the causative agent of African sleeping sickness, prohibitins are required for mitochondrial translation and maintaining mitochondrial membrane potential [32]. The diverse functions of SPFH proteins and their contributions to human disease emphasize the biological and clinical relevance of studying this protein superfamily.

\section{SPFH Protein Function in Non-Pathogenic Fungi}

Most of the knowledge for SPFH protein function in fungi has been acquired from experiments using non-pathogenic species [28,33-38]. In those studies, the mitochondrion has emerged as a focal point for understanding SPFH function. The mitochondrion is a specialized organelle found in eukaryotes and serves as the master regulator of metabolism, generating ATP via oxidative phosphorylation. Mitochondria also control key physiological activities, such as lipid synthesis and trafficking, aging, reactive oxygen species production, apoptosis, and cellular signaling.

In the baker's yeast Saccharomyces cerevisiae, the sole SPFH proteins, prohibitin 1 and prohibitin 2 (Phb1, Phb2), form ring-shaped complexes within the inner mitochondrial membrane and are associated with several mitochondrial functions [9]. Phb1 and Phb2 interact with Mdm33 to regulate mitochondrial ultrastructure and shape [34]. In addition, Phb1 and Phb2 interact with the chaperones Atp10 and Atp23 to assist formation of $\mathrm{F}_{1} \mathrm{~F}_{\mathrm{O}^{-}}$ ATP synthase [37]. Depletion of prohibitins reduces yeast life span and is characterized by abnormal mitochondrial structure and delayed mitochondrial segregation to budding daughter cells $[36,39,40]$.

Synthetic genetic arrays using a phb1 $1 \Delta$ mutant strain identified 35 genes that are required for viability or normal growth [36]. Interestingly, 31 of these genes encode mitochondrial proteins. 19 of these genes were associated with respiratory chain assembly and maintenance of mitochondrial structure. Major PHB1 genetic partners include YTA10, YTA11, and YME1 [36]. These genes encode proteins which belong to the conserved, ATP-dependent mitochondrial m-AAA protease family, which maintain the mitochondrial proteome [41]. Other PHB1 genetic partners include the cytochrome c complex subunitencoding genes, $\mathrm{COX} 6$ and $\mathrm{COX} 24$ [36]. In addition, 8 genes are required for the synthesis of the mitochondrial membrane lipids, cardiolipin and phosphatidylethanolamine. These partners include the highly conserved genes, UPS1 and UPS2 [36]. Lastly, prohibitin function and localization was associated with the presence of the yeast $\left[\mathrm{PSI}^{+}\right]$prion. Proteomic analysis revealed that aberrant mitochondrial function observed in $\left[\mathrm{PSI}^{+}\right]$prion yeast strains was caused, in part, by Phb1 mislocalization in the cytoplasm [35]. See Figure 1 for a summary of SPFH function in S. cerevisiae.

SPFH function has also been characterized in other non-pathogenic fungi. In the fission yeast Schizosaccharomyces pombe, Phb1 and Phb2 localize to the mitochondria [33]. Overexpression or deletion of the $p h b 2$ gene caused resistance to various antifungal drugs including terbinafine, fluconazole, amphotericin B, and clotrimazole [33]. Moreover, increased production of intracellular nitric oxide and reactive oxygen species were observed in Phb2 overexpression or deletion strains [33]. In contrast, only a $\Delta p h b 1$ deletion strain was resistant to antifungal drugs [33]. Additional genetic evidence showed that mitochondrial dysfunction caused by $p h b 2$ deletion and overexpression activated the oxidative stress response transcriptional regulator, Pap1, thus linking prohibitins to stress response signaling [33]. Paradoxically, S. cerevisiae phb2 $\Delta$ mutants were sensitive to fluconazole, amphotericin B, and clotrimazole, highlighting the differences of SPFH protein function in different yeast species [33]. However, the basis of this phenotype is unknown. 


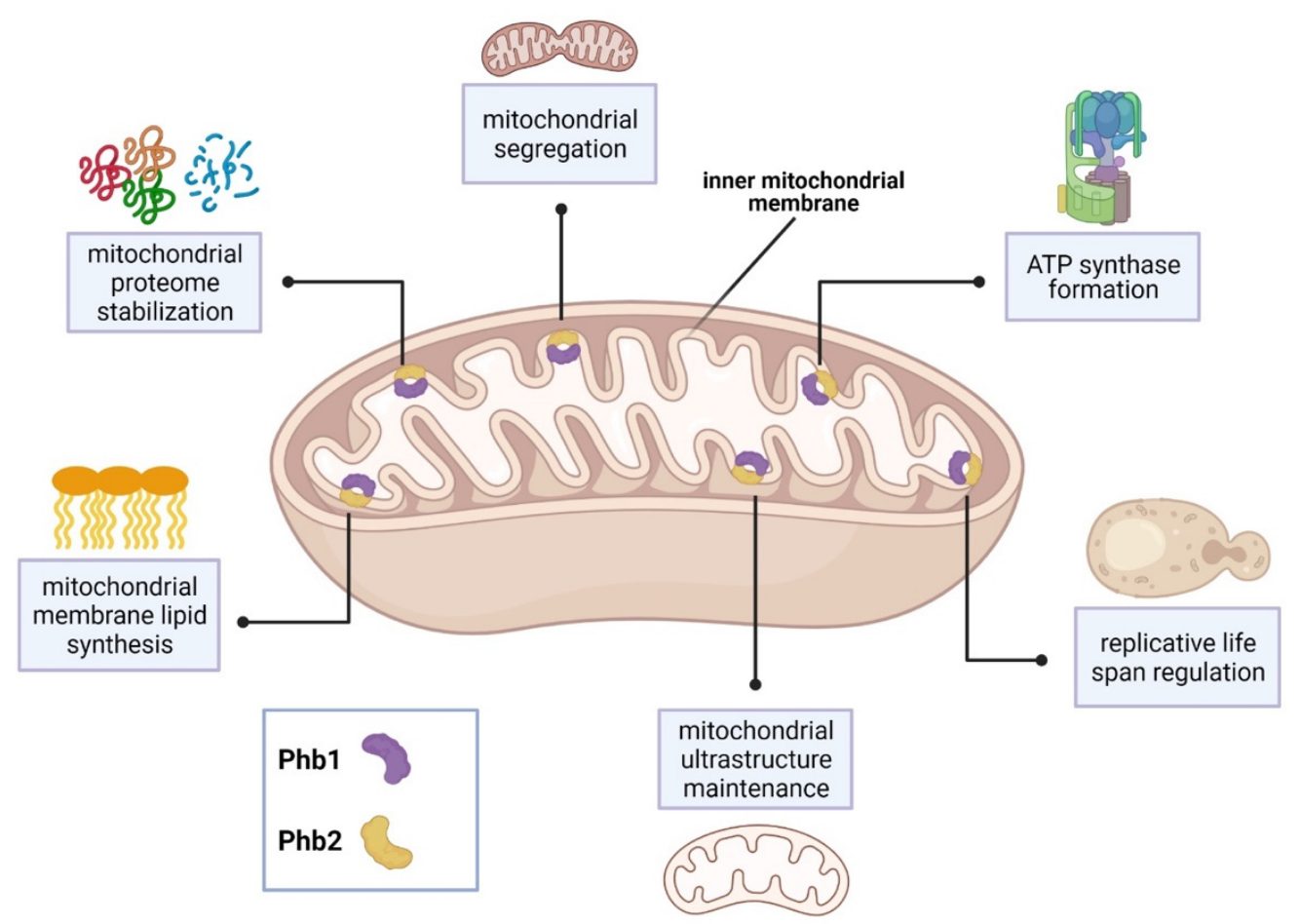

Figure 1. SPFH protein distribution and functions in S. cerevisiae. Phb1 and Phb2 form ring-shaped complexes that localize to the inner mitochondrial membrane. Known mitochondrial functions associated with the Phb1/Phb2 complex are depicted in the blue boxes. Figure adapted from references $[9,34-37,39]$ and created with Biorender.com.

Matrix-assisted laser desorption ionization-time of flight mass spectrometry (MALDITOF-MS) analyses on mitochondrial extracts identified three SPFH proteins (Phb1, Phb2 and Slp2) in the filamentous fungus, Neurospora crassa [38]. Consistent with the structural dynamics of prohibitins from mammals, nematodes, and yeast, N. crassa Phb1 and Phb2 localized to the inner mitochondrial membrane and formed large membrane complexes of various sizes. Notably, one high molecular weight prohibitin complex co-migrated with $m$-AAA protease MAP-1. This suggests that $m$-AAA proteins may physically interact with prohibitins in N. crassa, similar to observations with S. cerevisiae prohibitins [38]. Moreover, the stomatin, Slp2, was found to co-migrate in a high molecular weight complex with the N. crassa $i$-MMM protease homolog, IAP-1, suggesting that Slp2 and IAP-1 physically interact in the inner mitochondrial membrane [38]. Taken together, these findings demonstrate the importance of SPFH protein function in mitochondrial ultrastructure, respiratory function, and antifungal drug resistance.

\section{SPFH Protein Function in Pathogenic Fungi}

In fungal pathogens, mitochondria are required for virulence determinants including morphogenesis, drug susceptibility, cell wall biogenesis, and biofilm formation [42-44]. The knowledge underlying the molecular and cellular aspects of mitochondrial function in human pathogenic fungi is based primarily on studies in Candida albicans. C. albicans resides on mucosal tissue in the oral cavity and genitourinary and gastrointestinal tracts in a harmless commensal state [45]. Under permissive conditions, such as a change in host immunity, C. albicans causes superficial vaginal or oral mucosal infections. Disseminated invasive candidiasis is a major cause of morbidity and mortality for immunocompromised patients [46-48]. Mitochondrial function is critical for C. albicans commensalism and virulence [42]. Indeed, C. albicans cells treated with respiratory inhibitors display aberrant cell wall structure and increased macrophage recognition [49]. Moreover, mutations to fungal-specific mitochondrial genes, such as GOA1, NUO3, NUO4, and GEM1, attenuate 
virulence [50-53]. Genome-wide transcriptional profiling revealed that genes encoding proteins with mitochondrial functions are significantly upregulated following cell wall damage or osmotic stress [54-56]. The molecular details underlying C. albicans respiration have been reviewed $[42,45,57,58]$. The expanded role of the mitochondria in growth, stress adaptation, and virulence underscores the need to study all aspects of mitochondrial function. Therefore, SPFH proteins are excellent candidates to broaden our understanding of C. albicans mitochondrial dynamics.

The $C$. albicans genome includes five SPFH family members: PHB1, PHB2, PHB12, $S L P 2$, and SLP3 (stomatin-like protein 3) [59]. We were the first group to identify a role for SPFH proteins in C. albicans. We found that SLP3 transcription and protein localization significantly increased following treatment with oxidative, osmotic, cell wall, or plasma membrane stress agents, categorizing $S L P 3$ as a general stress response gene $[5,55,56]$. Slp3p formed visible puncta along the plasma membrane similar to mammalian stomatin complexes when viewed using fluorescence microscopy $[5,60]$. Slp3 plasma membrane localization was also confirmed via liquid chromatography-mass spectrometry (LC-MS/MS) and MALDI-TOF analysis on C. albicans plasma membrane extracts [6]. Interestingly, we also observed Slp3 localization at the vacuolar lumen; however, the basis for this result is unknown [5]. SLP3 transcription was significantly downregulated in cells undergoing the yeast-to-hyphae transition [61]. In concordance with this observation, Slp3 plasma membrane and vacuolar localization was absent in hyphal cells, categorizing Slp3 as a yeast-phase specific protein. [5]. A slp $3 \Delta /$ slp $3 \Delta$ homozygous mutant strain did not show a growth defect under standard growth conditions or when exposed to a variety of environmental stress conditions or antifungal drugs [5]. Moreover, the $\operatorname{slp} 3 \Delta / \mathrm{sl} 3 \Delta \Delta$ mutant did not display any apparent cell structure abnormality, organelle malfunction, or ion transport defect [5].

SPFH protein overproduction in mammals, nematodes, yeast, and mice causes a broad array of phenotypes, including drug resistance, aging, apoptosis, and tumorigenesis $[27,28,62]$. Consistent with these observations, we found that C. albicans Slp3 overproduction severely disrupted mitochondrial membrane potential and triggered apoptotic-like death specifically following prolonged exposure to oxidative stress [5]. Moreover, Slp3 overproduction in hyphal cells caused aberrant filament structure [5].

C. albicans Slp2, Phb1, Phb2, and Phb12 each contain a putative mitochondrial localization signal motif (our preliminary findings). We observed Slp2 mitochondrial localization (our preliminary findings), suggesting that the mitochondrial functions for prohibitins and Slp2 may be conserved. See Figure 2 for a summary of $C$. albicans SPFH protein function.

Other pathogenic fungi where SPFH protein function has been investigated include Aspergillus nidulans and Pneumocystis carinii. For both species, SPFH proteins were not associated with mitochondrial function. In A. nidulans, the flotillin, FloA, localized to the plasma membrane and mediates formation of plasma membrane sterol-rich domains. The stomatin, StoA, localized to the plasma membrane and endosomal/vacuolar-like structures and is required for hyphal polarized growth [63]. Heterologous expression of P. carinii prohibitin in human fibroblasts caused cell cycle arrest, suggesting a role for prohibitin in regulating proliferation and development [64]. Collectively, these findings highlight the expanded role of SPFH proteins in growth, filamentation, mitochondrial function, and stress signaling in pathogenic fungi. See Table 1 and Figure 3 for a summary and schematic of SPFH proteins with known functions in various fungal species. 


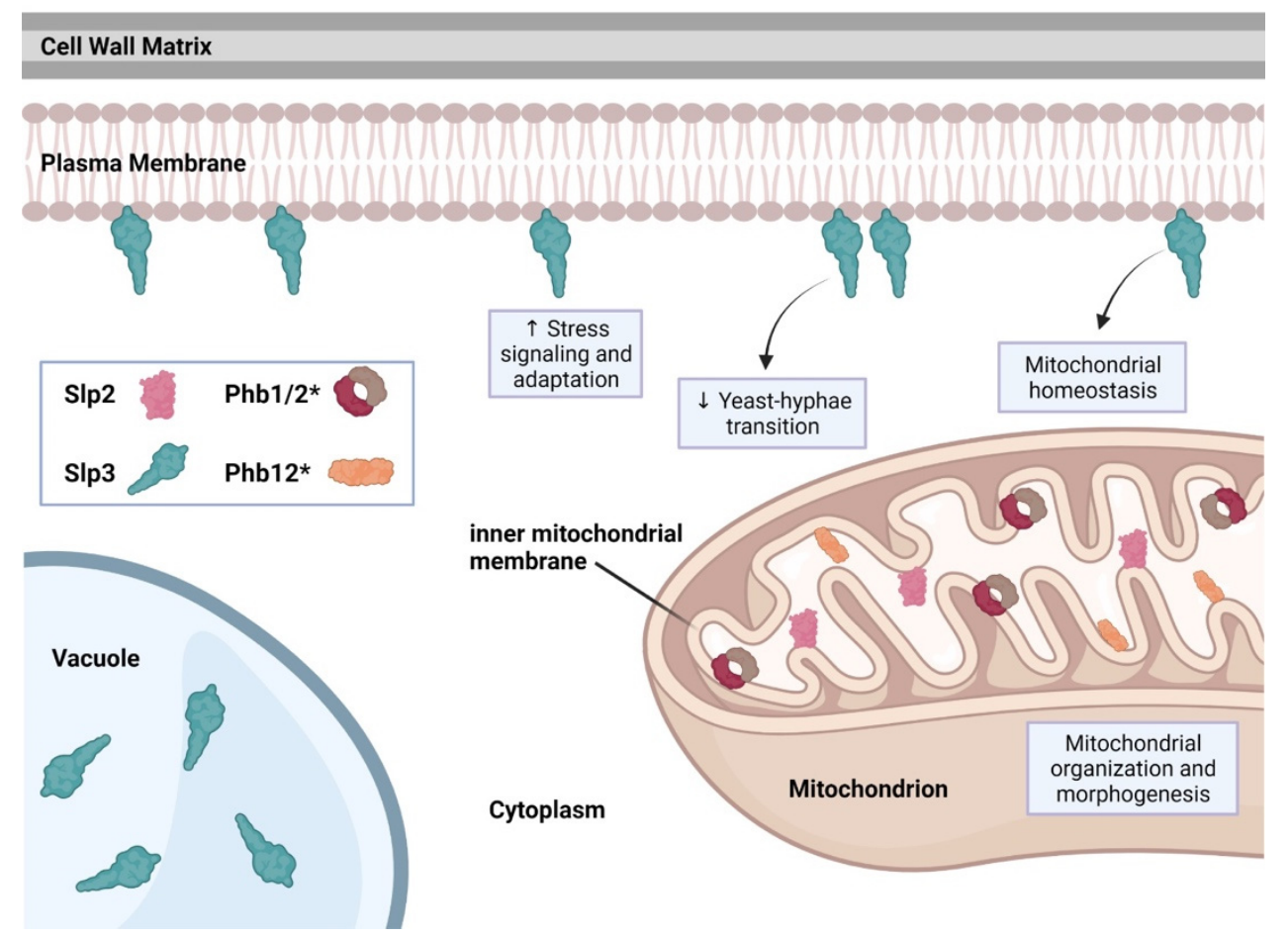

Figure 2. SPFH protein distribution and function in C. albicans. Illustration depicting the cellular localization of SPFH family members Slp2, Slp3, Phb1, Phb2, and Phb12. Asterisks (*) beside Phb1, $\mathrm{Phb2}$, and Phb12 denote that cellular localization of these proteins are only predicted and have not been experimentally confirmed. Biochemical and cytological analyses demonstrated that Slp3 localizes to the plasma membrane and vacuole, and Slp2 localizes to the mitochondria. Known functions associated with Slp3 are depicted in the blue boxes. Slp3 production is increased in response to environmental stress (boxed upward pointing arrow). Slp3 production is decreased in the yeast-tohyphae transition (boxed downward pointing arrow). Figure adapted from references $[5,6]$ and our unpublished findings and created with Biorender.com.

Table 1. SPFH proteins with known functions in fungi. SPFH protein localization and function for each fungal species listed have been experimentally confirmed in the referenced literature.

\begin{tabular}{|c|c|c|c|}
\hline Protein & Localization & Function & References \\
\hline \multicolumn{4}{|l|}{ S. cerevisiae } \\
\hline Phb1 and Phb2 & $\begin{array}{l}\text { inner mitochondrial membrane, } \\
\text { Phb1-Phb2 complex }\end{array}$ & $\begin{array}{l}\text { regulation of mitochondrial ultrastructure } \\
\text { and segregation, mitochondrial protein } \\
\text { stabilization, regulation of replicative life } \\
\text { span, regulation of mitochondrial } \\
\text { membrane lipid synthesis, involvement in } \\
\text { ATP synthase formation }\end{array}$ & {$[34-37,39,40]$} \\
\hline \multicolumn{4}{|l|}{ S. pombe } \\
\hline Phb1 & mitochondria & multi-drug resistance & [33] \\
\hline Phb2 & mitochondria & $\begin{array}{c}\text { multi-drug resistance, oxidative stress } \\
\text { signaling }\end{array}$ & [33] \\
\hline \multicolumn{4}{|l|}{ C. albicans } \\
\hline Slp3 & $\begin{array}{l}\text { plasma membrane, } \\
\text { vacuolar lumen }\end{array}$ & $\begin{array}{l}\text { yeast-specific general stress response } \\
\text { signaling, involved in maintenance of } \\
\text { mitochondrial membrane integrity }\end{array}$ & {$[5,6]$} \\
\hline \multicolumn{4}{|l|}{ N. crassa } \\
\hline Slp2 & mitochondria & interactions with $i$-MMM protein IAP-1 & [38] \\
\hline Phb1 and Phb2 & $\begin{array}{l}\text { inner mitochondrial membrane, } \\
\text { Phb1-Phb2 complex }\end{array}$ & interactions with $m$-AAA protease MAP-1 & [38] \\
\hline
\end{tabular}


Table 1. Cont.

\begin{tabular}{|c|c|c|c|}
\hline Protein & Localization & Function & References \\
\hline \multicolumn{4}{|l|}{ A. nidulans } \\
\hline FloA & plasma membrane & $\begin{array}{l}\text { formation of sterol-rich domains in plasma } \\
\text { membrane }\end{array}$ & [63] \\
\hline StoA & $\begin{array}{l}\text { plasma membrane, } \\
\text { endosome/vacuole }\end{array}$ & polarized hyphal growth & [63] \\
\hline \multicolumn{4}{|l|}{ P. carinii } \\
\hline Prohibitin & $\begin{array}{l}\text { inner mitochondrial membrane } \\
\text { (predicted) }\end{array}$ & $\begin{array}{c}\text { regulation of cell proliferation and } \\
\text { development }\end{array}$ & {$[64]$} \\
\hline
\end{tabular}

\section{S. cerevisiae Phb1}

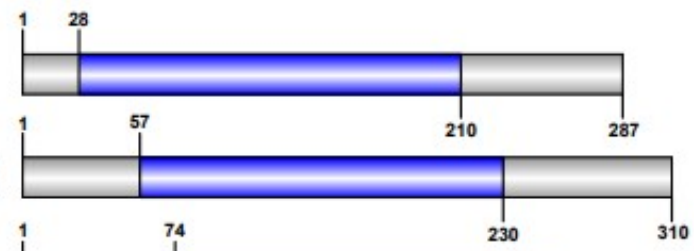

\section{S. cerevisiae Phb2}

S. pombe Phb1

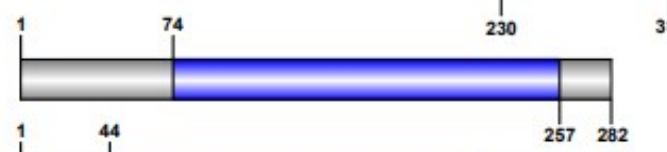

S. pombe Phb2

\section{N. crassa Phb1}

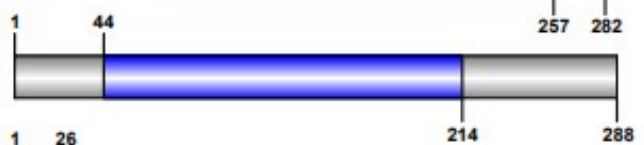

N. crassa Phb2

N. crassa SIp2

\section{C. albicans SIp3}

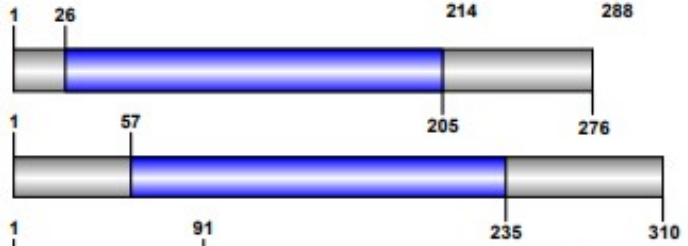

\section{A. nidulans FloA}

\section{A. nidulans StoA}

\section{P. carinii Prohibitin}

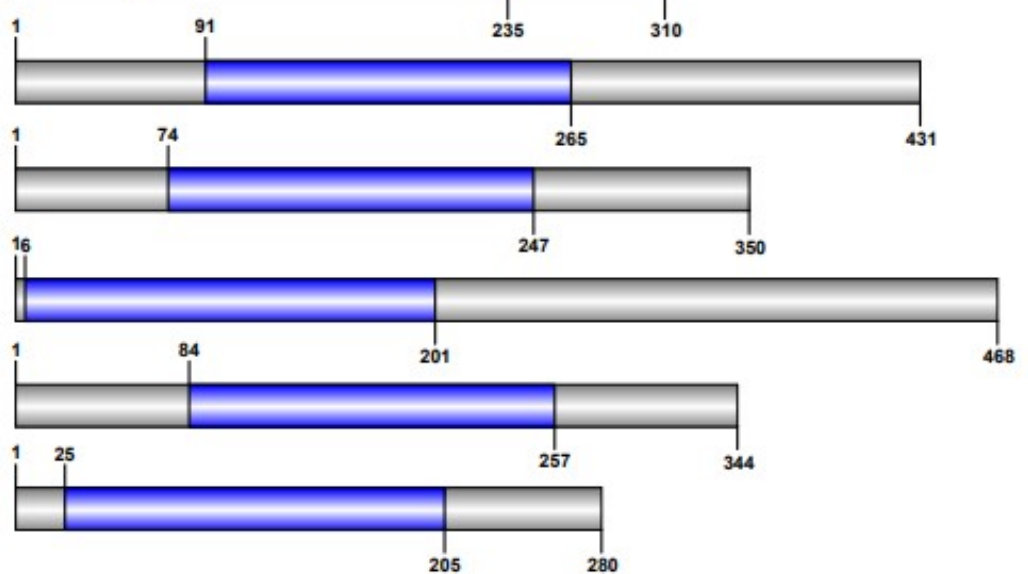

Figure 3. Schematic of fungal SPFH proteins. SPFH proteins that have been experimentally validated in fungi are depicted. Sequences for each protein were obtained from the Saccharomyces Genome Database, PomBase, Candida Genome Database, Aspergillus Genome Database, or UniProt [59,65,66]. SPFH/Band 7 domains (blue) were identified using InterProScan [67]. Schematics were constructed and drawn to scale using Illustrator for Biological Sequences [68].

\section{Perspectives and Future Directions}

It is critical that we advance our understanding of mitochondrial function in fungi to facilitate the development of new approaches for antifungal interventions [69]. The efficacy of antifungal drugs is limited due to mammalian tissue toxicity, parenteral formulations, and emerging drug resistant species $[45,70]$. Mitochondria are a premier pharmacological target in candidiasis treatment. The frequently prescribed antifungal drug, fluconazole, targets the lipid-synthesizing mitochondrial protein Erg11 [71].

The N- and C-terminal primary sequences between C. albicans and human SPFH proteins are highly divergent [5]; therefore, these regions can be potentially exploited in 
the development of novel antifungal therapeutics. For example, our findings that Slp3 overproduction disrupts $C$. albicans filamentation and depolarizes mitochondria can be used as a basis to develop a SPFH-derived antifungal strategy. In support of this idea, the therapeutic potential of targeting SPFH proteins have been recently demonstrated in bacteria, worms, and mammals [72]. The flavaglines class of natural chemical compounds inhibits mitochondrial PHB2 function, blocking mitophagy in human cancer cells [19]. Moreover, the small molecule synthetic compounds, OB-1 and OB-2 (oligomerization blockers 1 and 2), inhibit STOML3-dependent mechanosensation, thus alleviating painful diabetic neuropathy in mice [60].

Despite the progress made in revealing the structural characteristics and biochemical mechanisms governing SPFH protein function in model eukaryotes, we still do not know the function, physical and genetic targets, and mechanism-of-action for SPFH family members in pathogenic fungi. For example, the impact of C. albicans Slp3 on mitochondrial function suggests that SPFH proteins may mediate direct interactions between the plasma membrane or vacuole with the mitochondria. In S. cerevisiae, mitochondria directly associate with the plasma membrane and organelles such as the vacuole or endoplasmic reticulum to mediate lipid metabolism and mitochondrial biogenesis [73]. SPFH proteins have not yet been implicated in those interactions. In addition, the absence of an apparent phenotype in a slp $3 \Delta /$ slp $3 \Delta$ mutant suggests there may be functional redundancy among C. albicans SPFH proteins.

Thus, a comprehensive analysis for SPFH protein function in C. albicans and other fungal pathogens will require a proteomic and genetic approach along with a cost-effective in vivo infection assay. The recent development of optimized CRISPR-Cas9 genome editing methods in C. albicans [74] will facilitate the development of yeast strains containing mutations to multiple SPFH genes or SPFH genes and candidate SPFH protein targets to investigate genetic interactions. Hetero-oligomeric complexes with SPFH proteins and various transporter proteins as well as among SPFH stomatins and prohibitins have been observed in humans $[10,14,75]$. Co-Interacting Protein Identification Technology (Co-PIT) [76], and LC-MS/MS analyses can be used to determine the constituents of SPFH protein complexes in C. albicans.

Finally, the invertebrate planarian, Schmidtea mediterranea, has recently been shown to be an excellent host to study C. albicans pathogenesis in vivo [77]. The simple planarian anatomical design allows visualization of all phases of $C$. albicans infection, such as adherence, yeast-to-hyphae transition, and invasive growth in a cost-effective and time-saving manner [77]. To determine the role of SPFH proteins in C. albicans virulence, SPFH mutant and overexpressing strains can be analyzed in infection assays. Collectively, such findings will characterize the SPFH family in the context of a critical area in C. albicans biology: The molecular framework underlying mitochondrial function. In addition, the knowledge gained from C. albicans SPFH analysis will provide a detailed model for SPFH function in other fungal pathogens, such as Candida auris and Candida glabrata.

Author Contributions: Conceptualization, J.M.R.; writing-original draft preparation, M.Y.H. and J.M.R.; writing—review and editing, M.Y.H. and J.M.R.; visualization, M.Y.H. and J.M.R.; supervision, J.M.R.; project administration, J.M.R.; funding acquisition, J.M.R. All authors have read and agreed to the published version of the manuscript.

Funding: This research was funded by the National Institutes of Health (NIH) National Institute of General Medical Sciences (NIGMS) award SC3GM135016 to J.M.R.

Conflicts of Interest: The authors declare no conflict of interest.

\section{References}

1. Lapatsina, L.; Brand, J.; Poole, K.; Daumke, O.; Lewin, G.R. Stomatin-domain proteins. Eur. J. Cell Biol. 2012, 91, $240-245$. [CrossRef]

2. Browman, D.T.; Hoegg, M.B.; Robbins, S.M. The SPFH domain-containing proteins: More than lipid raft markers. Trends Cell Biol. 2007, 17, 394-402. [CrossRef] 
3. Rivera-Milla, E.; Stuermer, C.A.; Malaga-Trillo, E. Ancient origin of reggie (flotillin), reggie-like, and other lipid-raft proteins: Convergent evolution of the SPFH domain. Cell. Mol. Life Sci. 2006, 63, 343-357. [CrossRef]

4. Hinderhofer, M.; Walker, C.A.; Friemel, A.; Stuermer, C.A.; Moller, H.M.; Reuter, A. Evolution of prokaryotic SPFH proteins. BMC Evol. Biol. 2009, 9, 10. [CrossRef]

5. Conrad, K.A.; Rodriguez, R.; Salcedo, E.C.; Rauceo, J.M. The Candida albicans stress response gene Stomatin-Like Protein 3 is implicated in ROS-induced apoptotic-like death of yeast phase cells. PLoS ONE 2018, 13, e0192250. [CrossRef] [PubMed]

6. Cabezon, V.; Llama-Palacios, A.; Nombela, C.; Monteoliva, L.; Gil, C. Analysis of Candida albicans plasma membrane proteome. Proteomics 2009, 9, 4770-4786. [CrossRef] [PubMed]

7. Snyers, L.; Umlauf, E.; Prohaska, R. Oligomeric nature of the integral membrane protein stomatin. J. Biol. Chem. 1998, 273, 17221-17226. [CrossRef] [PubMed]

8. Hiebl-Dirschmied, C.M.; Adolf, G.R.; Prohaska, R. Isolation and partial characterization of the human erythrocyte band 7 integral membrane protein. Biochim. Biophys. Acta 1991, 1065, 195-202. [CrossRef]

9. Tatsuta, T.; Model, K.; Langer, T. Formation of membrane-bound ring complexes by prohibitins in mitochondria. Mol. Biol. Cell 2005, 16, 248-259. [CrossRef] [PubMed]

10. Da Cruz, S.; Parone, P.A.; Gonzalo, P.; Bienvenut, W.V.; Tondera, D.; Jourdain, A.; Quadroni, M.; Martinou, J.C. SLP-2 interacts with prohibitins in the mitochondrial inner membrane and contributes to their stability. Biochim. Biophys. Acta 2008, 1783, 904-911. [CrossRef] [PubMed]

11. Christie, D.A.; Kirchhof, M.G.; Vardhana, S.; Dustin, M.L.; Madrenas, J. Mitochondrial and plasma membrane pools of stomatinlike protein 2 coalesce at the immunological synapse during T cell activation. PLoS ONE 2012, 7, e37144. [CrossRef]

12. Dempwolff, F.; Schmidt, F.K.; Hervas, A.B.; Stroh, A.; Rosch, T.C.; Riese, C.N.; Dersch, S.; Heimerl, T.; Lucena, D.; Hulsbusch, N.; et al. Super Resolution Fluorescence Microscopy and Tracking of Bacterial Flotillin (Reggie) Paralogs Provide Evidence for Defined-Sized Protein Microdomains within the Bacterial Membrane but Absence of Clusters Containing Detergent-Resistant Proteins. PLoS Genet. 2016, 12, e1006116. [CrossRef] [PubMed]

13. Reuter, A.T.; Stuermer, C.A.; Plattner, H. Identification, localization, and functional implications of the microdomain-forming stomatin family in the ciliated protozoan Paramecium tetraurelia. Eukaryot. Cell 2013, 12, 529-544. [CrossRef] [PubMed]

14. Mairhofer, M.; Steiner, M.; Salzer, U.; Prohaska, R. Stomatin-like protein-1 interacts with stomatin and is targeted to late endosomes. J. Biol. Chem. 2009, 284, 29218-29229. [CrossRef]

15. Wai, T.; Saita, S.; Nolte, H.; Muller, S.; Konig, T.; Richter-Dennerlein, R.; Sprenger, H.G.; Madrenas, J.; Muhlmeister, M.; Brandt, U.; et al. The membrane scaffold SLP2 anchors a proteolytic hub in mitochondria containing PARL and the i-AAA protease YME1L. EMBO Rep. 2016, 17, 1844-1856. [CrossRef] [PubMed]

16. Rungaldier, S.; Umlauf, E.; Mairhofer, M.; Salzer, U.; Thiele, C.; Prohaska, R. Structure-function analysis of human stomatin: A mutation study. PLoS ONE 2017, 12, e0178646. [CrossRef] [PubMed]

17. Yokoyama, H.; Matsui, I. Crystal structure of the stomatin operon partner protein from Pyrococcus horikoshii indicates the formation of a multimeric assembly. FEBS Open Bio 2014, 4, 804-812. [CrossRef]

18. Wei, Y.; Chiang, W.C.; Sumpter, R., Jr.; Mishra, P.; Levine, B. Prohibitin 2 Is an Inner Mitochondrial Membrane Mitophagy Receptor. Cell 2017, 168, 224-238. [CrossRef]

19. Yan, C.; Gong, L.; Chen, L.; Xu, M.; Abou-Hamdan, H.; Tang, M.; Desaubry, L.; Song, Z. PHB2 (prohibitin 2) promotes PINK1-PRKN/Parkin-dependent mitophagy by the PARL-PGAM5-PINK1 axis. Autophagy 2020, 16, 419-434. [CrossRef]

20. Mitsopoulos, P.; Lapohos, O.; Weraarpachai, W.; Antonicka, H.; Chang, Y.H.; Madrenas, J. Stomatin-like protein 2 deficiency results in impaired mitochondrial translation. PLoS ONE 2017, 12, e0179967. [CrossRef]

21. Christie, D.A.; Lemke, C.D.; Elias, I.M.; Chau, L.A.; Kirchhof, M.G.; Li, B.; Ball, E.H.; Dunn, S.D.; Hatch, G.M.; Madrenas, J. Stomatin-like protein 2 binds cardiolipin and regulates mitochondrial biogenesis and function. Mol. Cell. Biol. 2011, 31, 3845-3856. [CrossRef] [PubMed]

22. Mitsopoulos, P.; Chang, Y.H.; Wai, T.; Konig, T.; Dunn, S.D.; Langer, T.; Madrenas, J. Stomatin-like protein 2 is required for in vivo mitochondrial respiratory chain supercomplex formation and optimal cell function. Mol. Cell. Biol. 2015, 35, $1838-1847$. [CrossRef]

23. Klipp, R.C.; Cullinan, M.M.; Bankston, J.R. Insights into the molecular mechanisms underlying the inhibition of acid-sensing ion channel 3 gating by stomatin. J. Gen. Physiol. 2020, 152, e201912471. [CrossRef] [PubMed]

24. Wetzel, C.; Hu, J.; Riethmacher, D.; Benckendorff, A.; Harder, L.; Eilers, A.; Moshourab, R.; Kozlenkov, A.; Labuz, D.; Caspani, O.; et al. A stomatin-domain protein essential for touch sensation in the mouse. Nature 2007, 445, 206-209. [CrossRef] [PubMed]

25. Huang, M.; Gu, G.; Ferguson, E.L.; Chalfie, M. A stomatin-like protein necessary for mechanosensation in C. elegans. Nature 1995, 378, 292-295. [CrossRef]

26. Chowdhury, I.; Thompson, W.E.; Thomas, K. Prohibitins role in cellular survival through Ras-Raf-MEK-ERK pathway. J. Cell. Physiol. 2014, 229, 998-1004. [CrossRef] [PubMed]

27. Bartolome, A.; Boskovic, S.; Paunovic, I.; Bozic, V.; Cvejic, D. Stomatin-like protein 2 overexpression in papillary thyroid carcinoma is significantly associated with high-risk clinicopathological parameters and BRAFV600E mutation. APMIS 2016, 124, $271-277$. [CrossRef]

28. Signorile, A.; Sgaramella, G.; Bellomo, F.; De Rasmo, D. Prohibitins: A Critical Role in Mitochondrial Functions and Implication in Diseases. Cells 2019, 8, 71. [CrossRef] 
29. Zhu, W.; Li, W.; Geng, Q.; Wang, X.; Sun, W.; Jiang, H.; Pu, X. Silence of Stomatin-Like Protein 2 Represses Migration and Invasion Ability of Human Liver Cancer Cells via Inhibiting the Nuclear Factor Kappa B (NF-kappaB) Pathway. Med. Sci. Monit. 2018, 24, 7625-7632. [CrossRef]

30. Matz, J.M.; Goosmann, C.; Matuschewski, K.; Kooij, T.W.A. An Unusual Prohibitin Regulates Malaria Parasite Mitochondrial Membrane Potential. Cell Rep. 2018, 23, 756-767. [CrossRef]

31. Cruz-Bustos, T.; Ibarrola-Vannucci, A.K.; Diaz-Lozano, I.; Ramirez, J.L.; Osuna, A. Characterization and functionality of two members of the SPFH protein superfamily, prohibitin 1 and 2 in Leishmania major. Parasit. Vectors 2018, 11, 622. [CrossRef] [PubMed]

32. Tyc, J.; Faktorova, D.; Kriegova, E.; Jirku, M.; Vavrova, Z.; Maslov, D.A.; Lukes, J. Probing for primary functions of prohibitin in Trypanosoma brucei. Int. J. Parasitol. 2010, 40, 73-83. [CrossRef] [PubMed]

33. Liu, Q.; Yao, F.; Jiang, G.; Xu, M.; Chen, S.; Zhou, L.; Sakamoto, N.; Kuno, T.; Fang, Y. Dysfunction of Prohibitin 2 Results in Reduced Susceptibility to Multiple Antifungal Drugs via Activation of the Oxidative Stress-Responsive Transcription Factor Pap1 in Fission Yeast. Antimicrob. Agents Chemother. 2018, 62, e00860-18. [CrossRef]

34. Klecker, T.; Wemmer, M.; Haag, M.; Weig, A.; Bockler, S.; Langer, T.; Nunnari, J.; Westermann, B. Interaction of MDM33 with mitochondrial inner membrane homeostasis pathways in yeast. Sci. Rep. 2015, 5, 18344. [CrossRef] [PubMed]

35. Sikora, J.; Towpik, J.; Graczyk, D.; Kistowski, M.; Rubel, T.; Poznanski, J.; Langridge, J.; Hughes, C.; Dadlez, M.; Boguta, M. Yeast prion [PSI+] lowers the levels of mitochondrial prohibitins. Biochim. Biophys. Acta 2009, 1793, 1703-1709. [CrossRef] [PubMed]

36. Osman, C.; Haag, M.; Potting, C.; Rodenfels, J.; Dip, P.V.; Wieland, F.T.; Brugger, B.; Westermann, B.; Langer, T. The genetic interactome of prohibitins: Coordinated control of cardiolipin and phosphatidylethanolamine by conserved regulators in mitochondria. J. Cell Biol. 2009, 184, 583-596. [CrossRef] [PubMed]

37. Osman, C.; Wilmes, C.; Tatsuta, T.; Langer, T. Prohibitins interact genetically with Atp23, a novel processing peptidase and chaperone for the F1Fo-ATP synthase. Mol. Biol. Cell 2007, 18, 627-635. [CrossRef]

38. Marques, I.; Dencher, N.A.; Videira, A.; Krause, F. Supramolecular organization of the respiratory chain in Neurospora crassa mitochondria. Eukaryot. Cell 2007, 6, 2391-2405. [CrossRef]

39. Kirchman, P.A.; Miceli, M.V.; West, R.L.; Jiang, J.C.; Kim, S.; Jazwinski, S.M. Prohibitins and Ras2 protein cooperate in the maintenance of mitochondrial function during yeast aging. Acta Biochim. Pol. 2003, 50, 1039-1056. [CrossRef]

40. Piper, P.W.; Jones, G.W.; Bringloe, D.; Harris, N.; MacLean, M.; Mollapour, M. The shortened replicative life span of prohibitin mutants of yeast appears to be due to defective mitochondrial segregation in old mother cells. Aging Cell 2002, 1, 149-157. [CrossRef]

41. Glynn, S.E. Multifunctional Mitochondrial AAA Proteases. Front. Mol. Biosci. 2017, 4, 34. [CrossRef]

42. Calderone, R.; Li, D.; Traven, A. System-level impact of mitochondria on fungal virulence: To metabolism and beyond. FEMS Yeast Res. 2015, 15, fov027. [CrossRef]

43. Mamouei, Z.; Singh, S.; Lemire, B.; Gu, Y.; Alqarihi, A.; Nabeela, S.; Li, D.; Ibrahim, A.; Uppuluri, P. An evolutionarily diverged mitochondrial protein controls biofilm growth and virulence in Candida albicans. PLoS Biol. 2021, 19, e3000957. [CrossRef]

44. Koch, B.; Traven, A. Mitochondrial Control of Fungal Cell Walls: Models and Relevance in Fungal Pathogens. Curr. Top. Microbiol. Immunol. 2020, 425, 277-296. [CrossRef] [PubMed]

45. Richard, A.; Calderone, C.J.C. (Eds.) Candida and Candidiasis, 2nd ed.; ASM Press: Washington, DC, USA, $2012 ;$ p. 524.

46. Sobel, J.D. Recurrent vulvovaginal candidiasis. Am. J. Obstet. Gynecol. 2016, 214, 15-21. [CrossRef]

47. Brown, G.D.; Denning, D.W.; Gow, N.A.; Levitz, S.M.; Netea, M.G.; White, T.C. Hidden killers: Human fungal infections. Sci. Transl. Med. 2012, 4, 165rv113. [CrossRef]

48. Pfaller, M.A.; Diekema, D.J. Epidemiology of invasive candidiasis: A persistent public health problem. Clin. Microbiol. Rev. 2007, 20, 133-163. [CrossRef]

49. Duvenage, L.; Walker, L.A.; Bojarczuk, A.; Johnston, S.A.; MacCallum, D.M.; Munro, C.A.; Gourlay, C.W. Inhibition of Classical and Alternative Modes of Respiration in Candida albicans Leads to Cell Wall Remodeling and Increased Macrophage Recognition. mBio 2019, 10, e02535-18. [CrossRef] [PubMed]

50. Koch, B.; Tucey, T.M.; Lo, T.L.; Novakovic, S.; Boag, P.; Traven, A. The Mitochondrial GTPase Gem1 Contributes to the Cell Wall Stress Response and Invasive Growth of Candida albicans. Front. Microbiol. 2017, 8, 2555. [CrossRef]

51. Li, D.; Chen, H.; Florentino, A.; Alex, D.; Sikorski, P.; Fonzi, W.A.; Calderone, R. Enzymatic dysfunction of mitochondrial complex I of the Candida albicans goa1 mutant is associated with increased reactive oxidants and cell death. Eukaryot. Cell 2011, 10, 672-682. [CrossRef] [PubMed]

52. Bambach, A.; Fernandes, M.P.; Ghosh, A.; Kruppa, M.; Alex, D.; Li, D.; Fonzi, W.A.; Chauhan, N.; Sun, N.; Agrellos, O.A.; et al. Goa1p of Candida albicans localizes to the mitochondria during stress and is required for mitochondrial function and virulence. Eukaryot. Cell 2009, 8, 1706-1720. [CrossRef] [PubMed]

53. Sun, N.; Parrish, R.S.; Calderone, R.A.; Fonzi, W.A. Unique, Diverged, and Conserved Mitochondrial Functions Influencing Candida albicans Respiration. mBio 2019, 10, e00300-19. [CrossRef]

54. Heredia, M.Y.; Ikeh, M.A.C.; Gunasekaran, D.; Conrad, K.A.; Filimonava, S.; Marotta, D.H.; Nobile, C.J.; Rauceo, J.M. An expanded cell wall damage signaling network is comprised of the transcription factors RIm1 and Sko1 in Candida albicans. PLoS Genet. 2020, 16, e1008908. [CrossRef] 
55. Marotta, D.H.; Nantel, A.; Sukala, L.; Teubl, J.R.; Rauceo, J.M. Genome-wide transcriptional profiling and enrichment mapping reveal divergent and conserved roles of Sko1 in the Candida albicans osmotic stress response. Genomics 2013, 102, 363-371. [CrossRef]

56. Rauceo, J.M.; Blankenship, J.R.; Fanning, S.; Hamaker, J.J.; Deneault, J.S.; Smith, F.J.; Nantel, A.; Mitchell, A.P. Regulation of the Candida albicans cell wall damage response by transcription factor Sko1 and PAS kinase Psk1. Mol. Biol. Cell 2008, 19, $2741-2751$. [CrossRef]

57. Duvenage, L.; Munro, C.A.; Gourlay, C.W. The potential of respiration inhibition as a new approach to combat human fungal pathogens. Curr. Genet. 2019, 65, 1347-1353. [CrossRef] [PubMed]

58. Joseph-Horne, T.; Hollomon, D.W.; Wood, P.M. Fungal respiration: A fusion of standard and alternative components. Biochim. Biophys. Acta 2001, 1504, 179-195. [CrossRef]

59. Skrzypek, M.S.; Binkley, J.; Binkley, G.; Miyasato, S.R.; Simison, M.; Sherlock, G. The Candida Genome Database (CGD): Incorporation of Assembly 22, systematic identifiers and visualization of high throughput sequencing data. Nucleic Acids Res. 2017, 45, D592-D596. [CrossRef]

60. Wetzel, C.; Pifferi, S.; Picci, C.; Gok, C.; Hoffmann, D.; Bali, K.K.; Lampe, A.; Lapatsina, L.; Fleischer, R.; Smith, E.S.; et al. Small-molecule inhibition of STOML3 oligomerization reverses pathological mechanical hypersensitivity. Nat. Neurosci. 2017, 20, 209-218. [CrossRef] [PubMed]

61. Nantel, A.; Dignard, D.; Bachewich, C.; Harcus, D.; Marcil, A.; Bouin, A.P.; Sensen, C.W.; Hogues, H.; van het Hoog, M.; Gordon, P.; et al. Transcription profiling of Candida albicans cells undergoing the yeast-to-hyphal transition. Mol. Biol. Cell 2002, 13, 3452-3465. [CrossRef]

62. Chen, T.W.; Liu, H.W.; Liou, Y.J.; Lee, J.H.; Lin, C.H. Over-expression of stomatin causes syncytium formation in nonfusogenic JEG-3 choriocarcinoma placental cells. Cell Biol. Int. 2016, 40, 926-933. [CrossRef]

63. Takeshita, N.; Diallinas, G.; Fischer, R. The role of flotillin FloA and stomatin StoA in the maintenance of apical sterol-rich membrane domains and polarity in the filamentous fungus Aspergillus nidulans. Mol. Microbiol. 2012, 83, 1136-1152. [CrossRef]

64. Narasimhan, S.; Armstrong, M.; McClung, J.K.; Richards, F.F.; Spicer, E.K. Prohibitin, a putative negative control element present in Pneumocystis carinii. Infect. Immun. 1997, 65, 5125-5130. [CrossRef]

65. Lock, A.; Rutherford, K.; Harris, M.A.; Hayles, J.; Oliver, S.G.; Bahler, J.; Wood, V. PomBase 2018: User-driven reimplementation of the fission yeast database provides rapid and intuitive access to diverse, interconnected information. Nucleic Acids Res. 2019, 47, D821-D827. [CrossRef]

66. Cherry, J.M.; Hong, E.L.; Amundsen, C.; Balakrishnan, R.; Binkley, G.; Chan, E.T.; Christie, K.R.; Costanzo, M.C.; Dwight, S.S.; Engel, S.R.; et al. Saccharomyces Genome Database: The genomics resource of budding yeast. Nucleic Acids Res. 2012, 40, D700-D705. [CrossRef]

67. Jones, P.; Binns, D.; Chang, H.Y.; Fraser, M.; Li, W.; McAnulla, C.; McWilliam, H.; Maslen, J.; Mitchell, A.; Nuka, G.; et al. InterProScan 5: Genome-scale protein function classification. Bioinformatics 2014, 30, 1236-1240. [CrossRef]

68. Liu, W.; Xie, Y.; Ma, J.; Luo, X.; Nie, P.; Zuo, Z.; Lahrmann, U.; Zhao, Q.; Zheng, Y.; Zhao, Y.; et al. IBS: An illustrator for the presentation and visualization of biological sequences. Bioinformatics 2015, 31, 3359-3361. [CrossRef]

69. Li, D.; Calderone, R. Exploiting mitochondria as targets for the development of new antifungals. Virulence 2017, 8, 159-168. [CrossRef]

70. Berman, J.; Krysan, D.J. Drug resistance and tolerance in fungi. Nat. Rev. Microbiol. 2020, 18, 319-331. [CrossRef]

71. Benhamou, R.I.; Bibi, M.; Steinbuch, K.B.; Engel, H.; Levin, M.; Roichman, Y.; Berman, J.; Fridman, M. Real-Time Imaging of the Azole Class of Antifungal Drugs in Live Candida Cells. ACS Chem. Biol. 2017, 12, 1769-1777. [CrossRef]

72. Wang, D.; Tabti, R.; Elderwish, S.; Djehal, A.; Chouha, N.; Pinot, F.; Yu, P.; Nebigil, C.G.; Desaubry, L. SFPH proteins as therapeutic targets for a myriad of diseases. Bioorg. Med. Chem. Lett. 2020, 30, 127600. [CrossRef] [PubMed]

73. Westermann, B. The mitochondria-plasma membrane contact site. Curr. Opin. Cell Biol. 2015, 35, 1-6. [CrossRef] [PubMed]

74. Nguyen, N.; Quail, M.M.F.; Hernday, A.D. An Efficient, Rapid, and Recyclable System for CRISPR-Mediated Genome Editing in Candida albicans. $m$ Sphere 2017, 2, e00149-17. [CrossRef] [PubMed]

75. Rungaldier, S.; Oberwagner, W.; Salzer, U.; Csaszar, E.; Prohaska, R. Stomatin interacts with GLUT1/SLC2A1, band 3/SLC4A1, and aquaporin-1 in human erythrocyte membrane domains. Biochim. Biophys. Acta 2013, 1828, 956-966. [CrossRef] [PubMed]

76. Pankow, S.; Bamberger, C.; Calzolari, D.; Bamberger, A.; Yates, J.R., 3rd. Deep interactome profiling of membrane proteins by co-interacting protein identification technology. Nat. Protoc. 2016, 11, 2515-2528. [CrossRef] [PubMed]

77. Maciel, E.I.; Jiang, C.; Barghouth, P.G.; Nobile, C.J.; Oviedo, N.J. The planarian Schmidtea mediterranea is a new model to study host-pathogen interactions during fungal infections. Dev. Comp. Immunol. 2019, 93, 18-27. [CrossRef] 